\title{
Linking community tolerance and structure with low metallic contamination: A field study on 13 biofilms sampled across the Seine river basin
}

\author{
Lise C. Fechner ${ }^{a, b, c, *}$, Catherine Gourlay-Francé ${ }^{a, c}$, Marie-Hélène Tusseau-Vuillemin ${ }^{d}$ \\ a Irstea Antony - Unité de Recherche Hydrosystèmes et Bioprocédés (HBAN), 1 rue Pierre-Gilles de Gennes, CS \\ 10030, F-92761 Antony Cedex, France \\ ${ }^{\mathrm{b}}$ AgroParisTech, F-75005 Paris, France \\ ${ }^{\mathrm{c}}$ FIRE, FR-3020, 4 Place Jussieu, 75005 Paris, France \\ d IFREMER - Technopolis, 40, 155 rue Jean-Jacques Rousseau, 92138 Issy-Les-Moulineaux, France
}

*: Corresponding author : Lise C. Fechner, tel.: +33 140966568 ; fax: +33 140966199 ;

email address : lise.fechner@irstea.fr

\begin{abstract}
:
It is difficult to assess the biological consequences of diffuse water contamination by micropollutants which are present in rivers at low, even sublethal levels. River biofilms, which respond quickly to changes of environmental parameters, are good candidates to acquire knowledge on the response of aquatic organisms to diffuse chemical contamination in the field. The study was designed as an attempt to link biofilm metal tolerance and metallic contamination in a field survey covering 13 different sampling sites in the Seine river basin (north of France) with low contamination levels. $\mathrm{Cd}$ and $\mathrm{Zn}$ tolerance of heterotrophic communities was assessed using a short-term toxicity test based on $\beta$ glucosidase activity. Metal tolerance levels varied between sites but there was no obvious correlation between tolerance and corresponding water contamination levels for $\mathrm{Cd}$ and $\mathrm{Zn}$. Indeed, metallic contamination at the sampling sites remained subtle when compared to water quality standards (only two sampling sites had either $\mathrm{Zn}$ or both $\mathrm{Cu}$ and $\mathrm{Zn}$ concentrations exceeding the Environmental Quality Standards set by the EU Water Framework Directive). Yet, multivariate analysis of the data using Partial Least Squares Regression revealed that both metallic and environmental parameters were important variables explaining the variability of metal tolerance levels. Automated Ribosomal Intergenic Spacer Analysis (ARISA) was also performed on both bacterial and eukaryotic biofilm communities from the 13 sampling sites. Multivariate analysis of ARISA fingerprints revealed that biofilms with similar tolerance levels have similar ARISA profiles. Those results confirm that river biofilms are potential indicators of low, diffuse contamination levels of aquatic systems.
\end{abstract}




\section{Graphical abstract :}

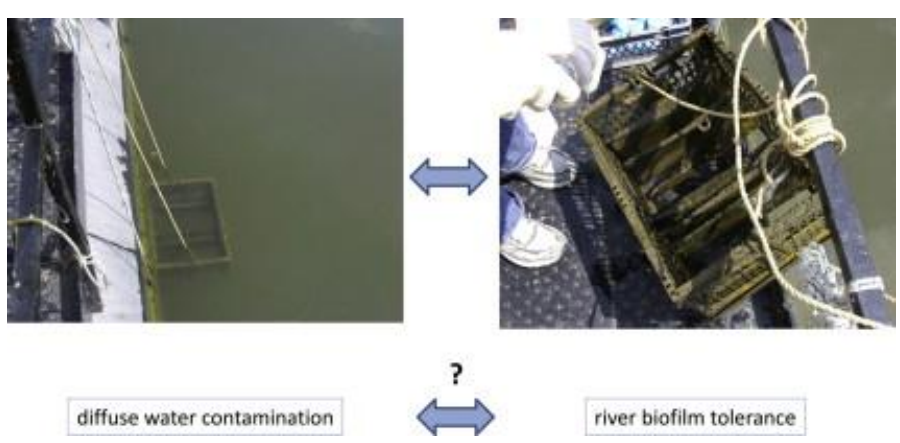

\section{Highlights}

River biofilms were collected on 13 sites with low metallic contamination levels. Multivariate analysis shows that biofilm metal tolerance was linked to contamination. Environmental parameters also modulate biofilm tolerance levels. Biofilms with similar tolerance levels have similar ARISA profiles. Biofilms are potential sensitive indicators of diffuse, low-level contamination.

Keywords: River biofilm ; Metal tolerance ; Toxicity ; ARISA ; PICT ; Community-level response 


\section{$41 \quad$ 1. Introduction}

42 Over the last decades, several authors have discussed the importance of measuring biological

43 responses at the community level in ecotoxicological studies (Clements and Rohr 2009,

44 Geiszinger et al. 2009). Indeed, current risk-assessment of toxicants remains largely based on

45 standardized, single-species tests performed in the laboratory, the results of which are then

46 extrapolated at the ecosystem level. Yet, the responses of single-species tests might differ from

47 responses occurring at the community level as important aspects of community ecology are not

48 considered: for instance, interactions between species within the exposed communities are not

49 taken into account (Schmitt-Jansen et al. 2008). Some studies have even suggested that current

50 environmental quality standards might thus not always be sufficient to protect organisms at the

51 community level (McClellan et al. 2008). Moreover, it is generally acknowledged that

52 community endpoints such as species richness and diversity are intimately linked to ecosystem

53 responses to stress and therefore essential to maintain ecosystem services (Clements and Rohr 54 2009).

55 A community-level approach like PICT (Pollution-Induced Community Tolerance) is an 56 interesting ecotoxicological tool to assess the impacts of toxicant exposures (Blanck et al. 2003).

57 The PICT approach proposes to assess shifts in community composition (from a sensitive

58 community to a more tolerant one) due to toxic exposures. It relies on the assumption that

59 sensitive components from the original community (species, genotypes or phenotypes) will be

60 gradually replaced by more tolerant ones during exposure, thus leading to an increase of the

61 global community tolerance. Tolerance development is measured as a shift in the Effect

62 Concentration (usually $\mathrm{EC}_{50}$ ) or Lethal Concentration $\left(\mathrm{LC}_{50}\right)$ obtained with a short-term toxicity 
63 test based on a physiological endpoint. Tests can be conducted on communities grown in

64 artificial environments (microcosms, mesocosms) or directly on communities collected in situ.

65 Interpretation of PICT measurements has proved to be more difficult in field studies either

66 because of co-tolerance, which occurs for chemicals with similar modes of actions or through the

67 development of unspecific defense mechanisms (such as mucilage for algal and bacterial

68 communities) (Schmitt-Jansen et al. 2008, Soldo and Behra 2000) or because of environmental

69 factors, such as light, nutrients, etc. (Serra et al. 2010, Guasch et al. 2002), which also affect

70 tolerance levels.

71 However, several PICT studies have investigated river biofilm tolerance to metals or

72 herbicides in the field and succeeded in linking tolerance acquisition to toxic exposure mostly by

73 focusing on one chemical (for instance zinc or atrazine: Blanck et al. 2003, Tlili et al. 2011,

74 Pesce et al. 2010, Admiraal et al. 1999) or more recently on multi-metallic pollution (Fechner et

75 al. 2012a, Fechner et al. 2012b), and usually in the same river upstream to downstream from a

76 polluted area. However, field studies attempting to link biological effects and chemical

77 contamination over wide ranges of sampling sites remain scarce. Moreover, current

78 contamination levels are characterized by large numbers of chemicals at low exposure

79 concentrations, which means that for historic contaminants like metals, the issue has shifted from

80 managing acute effects of single toxicants at high exposure levels (which might still occur for

81 instance in areas impacted by mining activities in the case of metals) to managing more subtle,

82 chronic effects of mixtures of chemicals (Schmitt-Jansen et al. 2008). Recent studies, including

83 the PICT studies mentioned above, point out that microbial communities might be good

84 indicators of chemical contamination, even of complex mixtures of chemicals at low exposure

85 levels such as found in the field. Indeed, microbial communities, which undergo fast changes in 
86 composition and function in response to changes in environmental parameters, are acknowledged

87 as potential interesting bioindicators of contamination (Sims et al. 2013, Sun et al. 2012,

88 Ricciardi et al. 2009). For instance, Sun et al. (2012) have succeeded in linking variations in

89 microbial community composition in sediment and environmental parameters including sediment

90 metallic contamination using Automated-Ribosomal Intergenic Spacer Analysis (ARISA) data

91 collected over six estuaries sites in Australia. In another recent study, Ancion et al. (2013) also

92 managed to link biofilm-associated metals with variations of bacterial communities using

93 ARISA fingerprints. However, to our knowledge, there are no field studies using tolerance

94 measurements on biofilms from a wide range of sampling sites impacted only by low, diffuse

95 multi-metallic pollution.

96 The present study was designed as a first attempt at linking metal tolerance and bacterial and

97 eukaryotic community composition of river biofilms to environmental parameters (including

98 physico-chemical parameters and metallic contamination levels) over a wide range of sampling

99 sites in the Seine river basin. Sampling sites were chosen to give a broad representation of

100 contamination levels in a large area impacted by diffuse, low metallic contamination (compared

101 to environmental quality standards). Biofilms were collected at 13 sites in the Seine river basin

102 (North of France) and their $\mathrm{Cd}$ and $\mathrm{Zn}$ tolerance levels were measured using a short-term toxicity

103 test based on $\beta$-glucosidase activity (which measures the tolerance of heterotrophic

104 communities). In parallel, bacterial and eukaryotic community composition was investigated

105 using ARISA. This fingerprinting technique, which exploits the length polymorphism of the 16S-

$10623 \mathrm{~S}$ intergenic spacer of bacteria and the ITS1-5.8S-ITS2 region of eukaryotes, had already

107 proved useful to assess shifts in community composition upstream to downstream from Paris in

108 the Seine river in previous studies (Fechner et al. 2012a, 2012b). The present study provides a 
109 larger survey of river biofilms and their use as possible indicators of urban contamination in a

110 context of diffuse, low and multi-metallic exposure.

111 


\section{Materials and Methods}

\section{$113 \quad 2.1$ Collection of river biofilms}

114 River biofilms were collected at 13 sites located in the Seine river basin (North of France,

115 Figure 1) after a two-weeks colonization period (see below for details about the collection of 116 biofilm samples).

117 Sites were sampled over three times from summer (sites 1 to 4 were sampled in early 118 September 2009) to autumn of the same year (sites 5 to 9 in October 2009 and sites 10 to 13 in 119 November 2009). Biofilms were collected on Low Density PolyEthylene membranes (4 to 7 120 membranes of $14 * 25 \mathrm{~cm}^{2}$ ) vertically attached to plastic crates, as described elsewhere (Fechner 121 et al. 2010a), immersed at each sampling site for two weeks at the edge of the river. Colonized 122 membranes were carried back to the laboratory in $250 \mathrm{~mL}$ glass-bottles placed in a cooler and 123 filled with mineral water (Grand Barbier, Mont-Dore, France, see Table S3). They were then 124 hand-scraped to remove periphyton and make biofilm suspensions in mineral water as in Fechner 125 et al. (2010a). Biofilms scraped from the membranes collected at one site were pooled together 126 to provide a unique biofilm suspension for each date and each site. Aliquots of the biofilm 127 suspensions were then assigned to various analyses for periphyton characterization or tolerance 128 measurements. To obtain ARISA fingerprints, $50 \mathrm{~mL}$ aliquots of biofilm suspensions (three 129 aliquots ie pseudo-replicates per sampling site) were centrifuged (15 minutes, $\left.10000 \mathrm{~g}, 4^{\circ} \mathrm{C}\right)$. 130 Supernatants were discarded and pellets were stored at $-80^{\circ} \mathrm{C}$ for further use.

\subsection{Water chemistry and metallic contamination}

133 Total and dissolved metal concentrations ( $\mathrm{Cd}, \mathrm{Cu}, \mathrm{Ni}, \mathrm{Pb}, \mathrm{Zn}, \mathrm{Co}, \mathrm{Cr}, \mathrm{Mn})$ as well as 17 134 physico-chemical parameters (temperature, $\mathrm{pH}$, conductivity, Total Suspended Solids 
135 concentration, Dissolved and Particulate Organic Carbon - DOC and POC - in water, as well as

136 major ions: $\mathrm{HCO}_{3}^{-}, \mathrm{Na}^{+}, \mathrm{K}^{+}, \mathrm{Mg}^{2+}, \mathrm{Ca}^{2+}, \mathrm{Cl}^{-}, \mathrm{SO}_{4}{ }^{2-}, \mathrm{NO}_{3}^{-}, \mathrm{PO}_{4}{ }^{3-}, \mathrm{NO}_{2}{ }^{-}, \mathrm{NH}_{4}{ }^{+}$, see Table $\mathrm{S} 1$ for

137 detailed values) were measured at week 0,1 and 2 of the study at each site. Labile metal

138 concentrations were measured using Diffusive Gradients in Thin films (DGTs: Zhang and

139 Davison 1995) immersed in the river at each site for one and two weeks (three replicates each).

140 To describe the metallic contamination of each sampling site in a more integrated way, we also

141 used the cumulative criterion unit (CCU) described by Clements et al. (2000) as the ratio of the

142 measured metal concentration (dissolved metal concentrations were used) to the US EPA

143 national recommended water quality criterion (National Recommended Water Quality Criteria

144 2009), summed for $\mathrm{Cd}, \mathrm{Cu}, \mathrm{Ni}, \mathrm{Pb}, \mathrm{Zn}$ and $\mathrm{Mn}$ at each sampling site:

$145 \mathrm{CCU}=\sum m_{i} / c_{i}$

146 where $m_{i}$ is the total dissolved metal concentration and $c_{i}$ the criterion value for the ith metal.

147 Criteria were corrected to account for modifications of water hardness for $\mathrm{Cd}, \mathrm{Cu}, \mathrm{Ni}, \mathrm{Pb}$ and $\mathrm{Zn}$

148 and a chronic criterion of $100 \mu \mathrm{g} / \mathrm{L}$ was used for Mn according to US-EPA guidelines (National

149 Recommended Water Quality Criteria 2009, see Table S2). In this study, we used CCU to

150 provide a unique, global value to compare sampling sites based on dissolved metal

151 contamination levels and general metal toxicity which is useful to assess statistical correlations

152 between biological responses (biofilm tolerance acquisition and structure modification) and 153 contamination data. 


\subsection{Biofilm characterization: biofilm descriptors and ARISA fingerprints}

158 Biofilms' dry weight (DW), ash-free dry weight (AFDW), and chlorophyll a (Chl-a)

159 concentrations were measured as described elsewhere (Fechner et al. 2010b). ARISA

160 fingerprints were obtained at each sampling date as in Fechner et al. (2010b). Briefly, DNA was

161 extracted from biofilm pellets using the Power Soil DNA Isolation Kit (Mobio Laboratories, Inc.,

162 Carlsbad, US). PCR amplification of bacterial 16S-23S ITS was performed using primers

163 ITSF/ITSReub with $1 \mathrm{X}$ PCR buffer, $1.25 \mathrm{U}$ of Thermo-Start Taq DNA polymerase (ABGene

164 Ltd, Epsom, UK), $0.2 \mathrm{mM}$ (each) dNTP, $1.5 \mathrm{mM}$ of $\mathrm{MgCl}_{2}, 0.5 \mathrm{mg} / \mathrm{mL}$ bovine serum albumin and

$1650.5 \mathrm{mM}$ ITSF and ITSReub (each). The mixture was held at $94{ }^{\circ} \mathrm{C}$ for $3 \mathrm{~min}$, followed by 35

166 cycles of $94{ }^{\circ} \mathrm{C}$ for $1 \mathrm{~min}, 56{ }^{\circ} \mathrm{C}$ for $1 \mathrm{~min}, 72{ }^{\circ} \mathrm{C}$ for $2 \mathrm{~min}$ and a final extension step at $72{ }^{\circ} \mathrm{C}$

167 for 10 min. Amplification of eukaryotic ITS1-5.8S-ITS2 regions was performed using primers

$1682234 \mathrm{C} / 3126 \mathrm{~T}$ and a similar protocol (annealing temperature: $57.5{ }^{\circ} \mathrm{C}$ ). Amplicons were

169 separated on an electrophoresis Bioanalyzer (2100 Electrophoresis Bioanalyzer, Agilent

170 Technologies) and fluorescence data was converted into electrophoregrams using 2100 Expert

171 software (Agilent Technologies). Electrophoregrams of pseudo-replicates were averaged in order

172 to obtain one ARISA profile per sampling site. ARISA profiles were then processed using the

173 StatFingerprints R package (Michelland et al., 2009).

174

\subsection{Metal tolerance measurements}

$176 \mathrm{Cd}$ and $\mathrm{Zn}$ tolerance levels of heterotrophic communities from sampled biofilms were

177 assessed using the normalized $\mathrm{EC}_{50}$ values obtained with the toxicity test based on $\beta$-glucosidase

178 activity developed by Fechner et al. (2010a, 2011). Briefly, biofilms were exposed to metals for

179 one hour (at least six concentrations of metal varying between 0.001 and $10 \mathrm{mM}$ were tested in 
180 triplicate for each toxicity test). Metal exposure levels during the toxicity tests were checked by

181 measuring metal concentrations in the stock solutions by flame AAS (Varian Inc., USA). $\beta$ -

182 glucosidase activity of the metal-exposed biofilms was measured spectrofluorometrically using

183 Methylumbelliferyl- $\beta$-D-glucopyranoside (Sigma-Aldrich). Fluorescence of 4-

184 Methyllumbelliferone (MUF) was measured using a LB 941 Tristar Ti fluorescence microplate

185 reader (Berthold Technologies, Bad Wildbad, Germany). Fluorescence measurements were

186 converted into MUF concentrations by calibrating the spectrofluorimeter with a range of MUF

187 solutions in demineralised water. Dose/effect curves were obtained by plotting the \% inhibition

188 of $\beta$-glucosidase activity as a function of metal concentration, and by fitting the data to the Hill

189 model and adjusting each parameter (maximum \% of inhibition, $\mathrm{EC}_{50}$ which is the concentration

190 at which $50 \%$ of the enzymatic activity is inhibited and Hill number) by non-linear regression.

$19195 \%$ confidence intervals around the fitted parameters were estimated using a Bootstrap method.

192 Community tolerance to metal was then assessed by calculation of a normalized $\mathrm{EC}_{50}$ value by

193 dividing the $\mathrm{EC}_{50}$ value by the Total Suspended Solids (TSS) concentration of the biofilm

194 suspension used for the short-term test (Fechner et al. 2010a).

195 This normalized $\mathrm{EC}_{50}$ value has been shown to provide a reliable and robust estimation of 196 metal tolerance that does not depend on experimental conditions (namely, the quantity of biofilm 197 used for the test), both on field and laboratory-exposed biofilms (Fechner et al. 2012a, 2010a, 198 2011). 


\subsection{Multivariate analysis}

201 PCA was performed on all the environmental parameters measured at the 13 sampling sites 202 including metallic contamination levels (mean values of physico-chemical data and metal 203 concentrations were used).

204 The effects of metal contamination on river biofilms' tolerance levels were examined using 205 Partial Least Squares (PLS) regression. PLS is a regression extension of PCA which is used to 206 connect two blocks of variables (X and Y) to each other. It derives its usefulness from its ability 207 to analyze data with noisy, collinear or even incomplete variables. Moreover, the precision of the 208 PLS model increases with the number of $X$ variables (Eriksson et al. 2006). In the present study, 209 PLS regression was performed with $\mathrm{Cd}$ and $\mathrm{Zn}$ tolerance levels and \% maximum of inhibition 210 (obtained during short-term tests performed with $\mathrm{Cd}$ and $\mathrm{Zn}$ ) as the $\mathrm{Y}$ variables and the 211 environmental parameters of the river water (physico-chemical parameters, metal concentrations) 212 and biofilm descriptors (DW, AFDW and Chl-a) as the X-variables. The quality of a PLS

213 regression model can be assessed both in terms of goodness of fit (the explained variance of both

$214 \mathrm{X}$ and $\mathrm{Y}$-variables calculated as $\mathrm{R}^{2} \mathrm{X}$ and $\mathrm{R}^{2} \mathrm{Y}$ ) and goodness of prediction $\left(\mathrm{Q}^{2}\right)$ which is

215 evaluated by cross-validation. The importance of each X-variable in the regression model is 216 summarized by its Variable Influence in the Projection (VIP) values, which takes into account 217 the amount of explained Y-variance and may be used to discriminate between X-variables. PLS 218 regression was performed using XLStat 2010 (Addinsoft, France). Before the PLS regression, all 219 data was log-transformed and normalized.

220 The influence of the environmental parameters on ARISA fingerprints was investigated using 221 non metric Multidimensional scaling (nMDS) performed on the Euclidian distances between 222 profiles $(\mathrm{n}=1000$ permutations). nMDS constructs a three-dimensional map showing each 
223 fingerprint as one plot so that highly similar fingerprints are plotted together. A stress value is

224 used to compute a goodness of fit analysis between the reproduced (in the nMDS map) and the

225 actual distances. A stress value $<0.1$ corresponds to a good ordination (Clarke 1993).

226 Analysis of similarity (ANOSIM) was also performed on the Euclidian distance matrix of both

227 bacterial and eukaryotic profiles (1000 permutations) to test the effect of grouping fingerprints

228 according to tolerance and CCU (for each parameter, profiles were grouped together as "high" or

229 "low" whether the corresponding parameter was above or below the mean calculated for all 13

230 sites). ANOSIM is a non-parametric permutation procedure which tests whether differences in

231 dissimilarity between groups exceed differences within groups. It generates a global test statistic

232 (R) which varies between -1 and 1 and the magnitude of which indicates the degree of

233 separation between groups of samples. A value of 1 indicates complete separation whereas a

234 value of 0 indicates no separation.

235

236 3. Results and discussion

$237 \quad 3.1$ Linking biofilm tolerance and metal contamination

238 The PCA score plot (Fig. 2a) separates sampling sites with higher contamination levels

239 (CCU $>0.30$ for sites $4,7,8,10,11$ and 13, Table 1) from the other sites along the first principal

240 component which is correlated to metallic contamination (Fig. 2b). Distribution of sampling sites

241 is less relevant along the second component (only 13.5\% of variability) but groups sites with

242 high $\mathrm{HCO}_{3}^{-}$and $\mathrm{pH}$ levels on the upper part of the graph (sites 7, 8, 9, 12, 13). Metal

243 concentrations (Table 2 and Table S4) remained low at all sampling sites for instance when

244 compared to environmental quality standards (EQS) of the Water Framework Directive (WFD)

245 or national recommended water quality criteria from the US-EPA. The only concentrations that 
246 exceeded quality standards (in this case WFD EQS) were for $\mathrm{Cu}$ and $\mathrm{Zn}$ at site 10 (with

247 dissolved concentrations of 1.9 and $9.1 \mu \mathrm{g} / \mathrm{L}$ respectively) and for $\mathrm{Zn}$ at site 13 (with a dissolved

$248 \mathrm{Zn}$ concentration of $46.7 \mu \mathrm{g} / \mathrm{L}$, which is considerably higher than the other sampling sites, the

249 mean dissolved $\mathrm{Zn}$ concentration being $6.5 \mu \mathrm{g} / \mathrm{L}$, Table 2). Dissolved $\mathrm{Cu}$ also reached the WFD

250 EQS $(1.4 \mu \mathrm{g} / \mathrm{L})$ at site 4 . In contrast, other PICT studies performed on field-sampled periphyton

251 report higher contamination levels, often due to former mining activities (Blanck et al. 2003,

252 Tlili et al. 2011, Admiraal et al. 1999, Lehmann et al. 1999). For instance, total Zn

253 concentrations reported in a large field study linking biofilm PICT measurements and $\mathrm{Zn}$

254 exposure concentrations (Blanck et al. 2003) over 15 sites across Europe varied between 3.9

$255 \mu \mathrm{g} / \mathrm{L}$ and more than $2 \mathrm{mg} / \mathrm{L}$ with a mean of $195.2 \mu \mathrm{g} / \mathrm{L}$ (in the present study the mean total $\mathrm{Zn}$

256 concentration is $13.6 \mu \mathrm{g} / \mathrm{L}$ and, except for a high concentration of $60.0 \mu \mathrm{g} / \mathrm{L}$ at site 13 , total $\mathrm{Zn}$

257 concentrations vary from 2.7 to $26.1 \mu \mathrm{g} / \mathrm{L}$, Table S4). Similarly, the mean dissolved $\mathrm{Zn}$

258 concentration at the reference site in another study (Tlili et al. 2011) is $36 \mu \mathrm{g} / \mathrm{L}$ and reaches 454

$259 \mu \mathrm{g} / \mathrm{L}$ at the most contaminated sampling site. The 13 sites of the present study therefore reflect

260 current urban contamination in the Seine river basin which is characterized by a mixture of

261 micropollutants at particularly low, sublethal concentrations (Uher et al. 2011, Tusseau-

262 Vuillemin et al. 2007). Field studies linking biological responses, especially community-level

263 parameters, and such low metallic contamination levels are scarce.

264 Metal tolerance levels (Table 1) varied between sites (5.9 and 8.0 factors were found between

265 the lowest and highest tolerance levels for $\mathrm{Cd}$ and $\mathrm{Zn}$ respectively). No correlation was found

266 between tolerance and corresponding contamination levels for $\mathrm{Cd}$ and $\mathrm{Zn}$ (for instance Pearson

267 correlation coefficient $\mathrm{R}=0.08$ and 0.13 for dissolved $\mathrm{Cd} / \mathrm{Cd}$ tolerance and dissolved $\mathrm{Zn} / \mathrm{Zn}$

268 tolerance respectively) or between tolerance and $\mathrm{CCU}(\mathrm{R}=0.12$ and 0.22 for $\mathrm{Cd}$ and $\mathrm{Zn}$ 
respectively). The absence of correlation is not totally surprising considering the very low

270 metallic concentrations registered at those sampling sites. The maximum $\%$ inhibition of $\beta$ -

271 glucosidase activity were estimated along with $\mathrm{EC}_{50}$ values from the dose/effect curves by fitting

272 the test data to the model (Table 1). A maximum \% inhibition below $100 \%$ means that $\beta$ -

273 glucosidase activity cannot be fully inhibited during short-term metal exposure even at high

274 metal concentrations. A decrease of this parameter has previously been observed as tolerance

275 levels increased for biofilms exposed to metals either in the laboratory or in the field (Fechner et

276 al. 2012a, 2011, 2012c). In the present study, the maximum \% inhibition is also negatively

277 correlated to tolerance $(\mathrm{R}=0.72, \mathrm{p}-$ value $=0.006$ for $\mathrm{Cd}$ and $\mathrm{R}=0.49, \mathrm{p}-$ value $=0.09$ for $\mathrm{Zn})$

278 and even to $\mathrm{CCU}(\mathrm{R}=0.61, \mathrm{p}-$ value $=0.03$ for $\mathrm{Cd}$ and $\mathrm{R}=0.62, \mathrm{p}-$ value $=0.02$ for $\mathrm{Zn}$ ).

279 These results confirm that variations in maximum \% inhibition provide an additional biological 280 response of river biofilms to toxic exposure.

281 Those results also confirm that, as could be expected for a field study covering a rather large 282 geographical area and different sampling sites with low contamination levels, establishing a link

283 between tolerance and contamination is not obvious. For instance, the biofilm collected at site 1

284 has the highest $\mathrm{Cd}$ and $\mathrm{Zn}$ tolerance levels (Table 1) whereas metal concentrations at this site 285 were all below the mean calculated for the 13 sites (except for total $\mathrm{Cu}$ see Table S4 for details).

286 This sampling site is also characterized by a low conductivity, TSS, $\mathrm{pH}$ and low ionic 287 concentrations (see Table S1 for details). It is thus possible that physico-chemical characteristics 288 of the river water play a role on metal speciation and bioavailability in situ and consequently on 289 biofilms' response to metals. Environmental parameters other than metallic concentrations must 290 definitely be taken into account to correctly interpret tolerance measurements, especially in the 291 case of low exposure levels which do not engender strong and obvious tolerance development. 
3.2 Community tolerance: an integrative response to environmental parameters?

294 Multivariate analysis was thus used to explore further the relationships between metal 295 tolerance, maximum \% inhibition and all the environmental parameters likely to modulate 296 community tolerance. PLS produced a six-component regression model with a good fit (84 and $29797 \%$ of explained variance for the $\mathrm{X}$ and $\mathrm{Y}$ variables respectively) and with good predictive 298 ability $\left(\mathrm{Q}^{2}=0.78\right.$, see Table S5 for details on model parameters $)$. PLS revealed that both metallic 299 and physico-chemical parameters were important variables explaining the variability of metal 300 tolerance levels (Table 3).

301 Among the most influential parameters in the regression model (VIP > 1), $\mathrm{Zn}$ and $\mathrm{Cd}$ 302 concentrations (total for both metals and also dissolved $\mathrm{Zn}$ ) appear, as well as other metallic 303 concentrations $(\mathrm{Cr}, \mathrm{Pb}$ and $\mathrm{Ni}$ ). Finding metallic concentrations other than $\mathrm{Cd}$ and $\mathrm{Zn}$ among the 304 influential variables is not totally surprising as co-tolerance phenomenons can be due to either 305 specific or non-specific defense mechanisms. Among specific defense mechanisms, evidence of 306 multi-resistance to $\mathrm{Pb}, \mathrm{Cd}$ and $\mathrm{Zn}$ (a family of transport protein) has already been described in 307 bacterial species (Nies 2003). Multi-resistance to Co, Zn, Cd and Ni has equally been linked to 308 the presence of export proteins (Nies 2003) which is interesting as Co also appears as one of the 309 important $\mathrm{X}$ variables in the regression model (VIP > 0.95).

310 It is also interesting to note that for $\mathrm{Cd}$ and $\mathrm{Zn}$, labile concentrations have a lower significance 311 in the regression model (VIP < 0.9) than total concentrations. DGT-labile metal concentrations

312 are an estimate of time-weighted average concentrations of inorganic and weakly-complexed

313 dissolved metals (Tusseau-Vuillemin et al. 2007). In a previous study on three sites located along

314 the Seine river (Fechner et al. 2012a), multivariate analysis suggested that labile and dissolved 
315 metal concentrations might be better related to tolerance acquisition for metals like $\mathrm{Cd}$ and $\mathrm{Zn}$

316 than total metal concentrations. Indeed DGT-labile metals have been shown to provide

317 reasonably good estimations of bioavailable metal concentrations to various aquatic organisms

318 compared to total and dissolved metals (Buzier et al. 2006). Yet labile copper concentrations

319 have also been shown to underestimate copper bioavailability to bryophytes, especially at rather

320 low concentrations (Ferreira et al. 2008). As regards biofilms more specifically, metal

321 bioavailability and toxicity mechanisms towards biofilm microorganisms are complex and

322 depend on the biofilm sample, the metal considered and metal speciation (Bradac et al. 2010,

323 Meylan et al. 2004). More field data needs to be obtained in order to investigate further the link

324 between metal speciation in situ and biofilm metal tolerance.

$325 \mathrm{pH}, \mathrm{POC}, \mathrm{NH}_{4}^{+}, \mathrm{Na}^{+}, \mathrm{Mg}^{2+}$ and water alkalinity are also found among the most important 326 physico-chemical parameters. The coefficients associated with the Y variables (Table 3) show 327 that an increase in $\mathrm{pH}, \mathrm{Mg}^{2+}, \mathrm{Na}^{+}$and alkalinity are all negatively correlated with tolerance 328 acquisition in the regression model. This is not totally surprising as a parameter like $\mathrm{Mg}^{2+}$ is 329 known to influence metal bioavailability by inhibiting the complexation of metal ions to 330 biological ligands and thus might decrease metal toxicity towards aquatic organisms (Niyogi and 331 Wood 2004) (and thus probably tolerance acquisition by biofilm microorganisms). Similarly, an 332 increase of $\mathrm{pH}$ or water alkalinity might be correlated with a decrease of tolerance as both 333 influence metal speciation (for instance by metal precipitation or by the appearance of other toxic 334 inorganic species such as $\mathrm{MeOH}^{+}$) and therefore metal toxicity (Niyogi and Wood 2004). The 335 influence of parameters like POC and $\mathrm{NH}_{4}{ }^{+}$is less easy to interpret. POC might be a source of 336 contamination for biofilm microorganisms as metal-contaminated particulate matter from the 337 river water might bind to the biofilm matrix. Moreover, $\mathrm{Na}^{+}, \mathrm{POC}, \mathrm{NH}_{4}{ }^{+}$or any environmental 
338 parameter might play a role in the species composition of the sampled biofilms and thus in their

339 sensitivity to metals: $\mathrm{pH}$ could be a good example as it has a strong influence on bacterial

340 community structure (Fierer et al. 2007). It is also interesting to note that biofilm descriptors

341 such as biofilm DW and Chl-a are among the most influential variables as those parameters were

342 not correlated with tolerance levels in a previous study on biofilms collected along the Seine

343 river (Fechner et al. 2012a). Modifications of those biofilm descriptors might also indicate

344 changes in biofilm species composition (for instance a varying Chl-a concentration might reveal

345 changes in algal species composition) or in the matrix composition (a change in DW might be

346 related to a modification of exopolysaccharides - EPS - production in the matrix or an increase of

347 mineral particles from the river being retained within the matrix). Analysis of ARISA

348 fingerprints brings further information on the modifications of biofilm community structure 349 among the 13 sampling sites.

\subsection{Linking community composition and metal tolerance}

352 Tolerance acquisition can be related to genetic and/or phenotypic adaptation and selection 353 processes within the exposed community. In an attempt to better understand the genetic 354 mechanisms at the root of tolerance acquisition in the 13 biofilms sampled in this study, we used

355 ARISA as a fast and efficient technique to visualize gross genetic modifications of community 356 structure. nMDS of both bacterial and eukaryotic ARISA fingerprints was used to visualize 357 groups of biofilms with similar structure (assessed with ARISA fingerprints). Interestingly, 358 bacterial profiles (Figure 3a shows a 2D projection of the 3D nMDS plot) appear to be grouped 359 according to Zn tolerance levels as confirmed by ANOSIM (Global ANOSIM, R = -0.175, p360 value $=0.08)$ and not $\mathrm{Cd}$ tolerance levels $(\mathrm{R}=-0.021, \mathrm{p}$-value $=0.49)$. Similarly, eukaryotic 
361 profiles (Figure $3 \mathrm{~b}$ ) are better grouped according to $\mathrm{Zn}$ tolerance levels $(\mathrm{R}=0.147$, $\mathrm{p}$-value $=$

$3620.1)$ than to $\mathrm{Cd}$ tolerance levels $(\mathrm{R}=0.03$, $\mathrm{p}$-value $=0.33)$. Moreover, ANOSIM reveals that

363 ARISA profiles are also grouped according to CCU levels for eukaryotic communities $(\mathrm{R}=$

$3640.197, \mathrm{p}$-value $=0.14)$ and to a lesser extent for bacterial communities $(\mathrm{R}=-0.206, \mathrm{p}$-value $=$

365 0.92). nMDS reveals here that differences/similarities in community structure of both bacterial

366 and eukaryotic microorganisms are related to differences/similarities between tolerance levels.

367 Therefore it is probable that selection processes (disappearance of sensitive species and

368 development of metal-tolerant ones) were involved in tolerance acquisition. It is also probable

369 that metal contamination (characterized here by CCU levels) modifies community structure.

370 However, it is difficult to interpret further modifications of ARISA fingerprints and their link to

371 environmental parameters or tolerance levels.

372 Although ARISA remains a technique for a global, gross analysis of community structure

373 (only main Operational Taxonomic Units or OTUs are detected and the number of OTUs

374 detected is not always easily interpreted in terms of microbial diversity (Fechner et al. 2010b,

375 Bent and Forney 2008)), biofilms with similar profiles are likely to be composed of the same

376 dominant OTUs. A more thorough investigation of the taxonomic composition of biofilm

377 samples, for instance through high-throughput DNA sequencing or a gene-related molecular

378 approach, might provide further information as, for instance, the presence of metal-resistance

379 species or genes within the communities that have high metal tolerance levels. Considering the

380 results obtained here, it would be interesting to study both prokaryotic (using $16 \mathrm{~S}$ related assays)

381 and eukaryotic (18S) biofilm communities to investigate the impacts of water contamination. Yet

382 DNA sequencing still remains relatively expensive, especially when compared to ARISA which

383 offers a fast and cost-effective means to screen community structure and identify changes in both 
384 community structure and diversity in relation with environmental parameters (Magbanua et al.

385 2013). Investigating the presence of metal-resistance genes within the communities would also

386 be an interesting perspective to further explore biofilms' response to metallic contamination.

\section{Conclusions}

389 This study confirms the importance of both bacterial and eukaryotic microorganisms from

390 river biofilms to investigate the influence of contamination on aquatic ecosystems. Several

391 studies have already pointed at the sensitivity of microbial communities to the influence of

392 contamination, for instance when compared to the eukaryotic macrofauna currently used for

393 water quality monitoring such as fish, algae or macroinvertebrates. River biofilms collected in

394 this study respond to modifications of metallic concentrations in a context of subtle, diffuse

395 contamination, that is to say with low metal concentrations compared to international

396 environmental quality standards. Although tolerance acquisition is not easily interpreted in

397 relation to those particularly low metallic contamination levels, multivariate analysis highlights

398 links between tolerance and metallic exposure. Those results show that a PICT approach is

399 relevant to assess the impacts of low metallic contamination although more data is needed to

400 understand the link between metal speciation in situ and metal tolerance of river biofilms.

401 ARISA fingerprints are grouped according to tolerance levels showing that tolerance acquisition

402 is most probably related to modifications of community structure.

403 Both types of biological responses (tolerance acquisition and modifications of community

404 structure) cannot be unequivocally attributed to metal contamination; the individual effects of all

405 environmental parameters that influence biofilm composition and are identified as important in

406 this study cannot be distinguished. Further studies are thus needed to investigate more closely 
407 responses to low contamination at the community level, for instance by carefully choosing a 408 sample group of sites with a known range of contamination levels and physico-chemical 409 parameters so that the effects of confounding factors (physico-chemical parameters) can be 410 statistically deduced from water contamination. However, the study confirms that river biofilms 411 have a great potential to be used as sensitive indicators of diffuse, low-level metallic 412 contamination.

\section{Acknowledgement}

415 This study was supported by ONEMA (Office National de l'Eau et des Milieux Aquatiques).

416 Data (environmental parameters) collected during the Bioconbas project funded by Agence de 417 l'Eau Seine Normandie was used for interpretation and discussion of biofilm parameters. The 418 authors would like to thank Emmanuelle Uher for her great help with metal analysis and Sophie 419 Ayrault for providing access to the ICP-MS platform at the LSCE. We are also grateful to Cécile 420 Mirande-Bret and Aurélie Germain for their valuable help in the field and in the laboratory, and 421 to Julien Guieu for editing the English version of the manuscript.

\section{$422 \quad$ Supporting information}

423 Details about physico-chemical data, metal concentrations and detailed model parameters of 424 the PLS regression are available as Supporting Information. 
Clements, W.H., Rohr, J.R. 2009. Community responses to contaminants: using basic ecological principles to predict ecotoxicological effects Environmental Toxicology and Chemistry 28(9), 430 1789-1800.

431 Geiszinger, A., Bonnineau, C., Faggiano, L., Guasch, H., Lopez-Doval, J.C., Proia, L., Ricart, 432 M., Ricciardi, F., Romani, A., Rotter, S., Munoz, I., Schmitt-Jansen, M., Sabater, S. 2009. The 433 relevance of the community approach linking chemical and biological analyses in pollution assessment. TrAC - Trends in Analytical Chemistry 28(5), 619-626. Schmitt-Jansen, M., Veit, U., Dudel, G., Altenburger, R. 2008. An ecological perspective in aquatic ecotoxicology: Approaches and challenges. Basic and Applied Ecology 9(4), 337-345.

McClellan, K., Altenburger, R., Schmitt-Jansen, M. 2008. Pollution-induced community tolerance as a measure of species interaction in toxicity assessment. Journal of Applied Ecology 45(5), 1514-1522. Blanck, H., Admiraal, W., Cleven, R.F.M.J., Guasch, H., Hoop, M.A.G.T.v.d., Ivorra, N., Nyström, B., Paulsson, M., Petterson, R.P., Sabater, S., Tubbing, G.M.J. 2003. Variability in Zinc Tolerance, Measured as Incorporation of Radio-Labeled Carbon Dioxide and Thymidine, in Periphyton Communities Sampled from 15 European River Stretches. Archives of Environmental Contamination and Toxicology 44(1), 17-29. communities and their tolerance to copper, zinc, nickel and silver. Aquatic Toxicology 47(3-4), 181-189.

Serra, A., Guasch, H., Admiraal, W., Van Der Geest, H.G., Van Beusekom, S.A.M. 2010. Influence of phosphorus on copper sensitivity of fluvial periphyton: The role of chemical, physiological and community-related factors. Ecotoxicology 19(4), 770-780. oligotrophic calcareous streams. Journal of Phycology 38(2), 241-248. Tlili, A., Corcoll, N., Bonet, B., Morin, S., Montuelle, B., Bérard, A., Guasch, H. 2011. In situ spatio-temporal changes in pollution-induced community tolerance to zinc in autotrophic and heterotrophic biofilm communities. Ecotoxicology 20, 1823-1839.

Pesce, S., Margoum, C., Montuelle, B. 2010. In situ relationships between spatio-temporal variations in diuron concentrations and phototrophic biofilm tolerance in a contaminated river. Water Research 44(6), 1941-1949.

Admiraal, W., Blanck, H., Buckert-de Jong, M., Guasch, H., Ivorra, N., Lehmann, V., Nystrom, B.A.H., Paulsson, M., Sabater, S. 1999. Short-term toxicity of zinc to microbenthic algae and bacteria in a metal polluted stream. Water Research 33(9), 1989-1996.

Fechner, L.C., Gourlay-Francé, C., Bourgeault, A., Tusseau-Vuillemin, M.H. 2012a. Diffuse urban pollution increases metal tolerance of natural heterotrophic biofilms. Environmental Pollution 162, 311-318.

Fechner, L.C., Versace, F., Gourlay-Francé, C., Tusseau-Vuillemin, M.H. 2012b. Adaptation of copper community tolerance levels after biofilm transplantation in an urban river. Aquatic Toxicology 106-107, 32-41. 
Sims, A., Zhang, Y., Gajaraj, S., Brown, P.B., Hu, Z. 2013. Toward the development of microbial indicators for wetland assessment. Water Research 47(5), 1711-1725. Sun, M.Y., Dafforn, K.A., Brown, M.V., Johnston, E.L. 2012. Bacterial communities are sensitive indicators of contaminant stress. Marine Pollution Bulletin 64(5), 1029-1038.

Ricciardi, F., Bonnineau, C., Faggiano, L., Geiszinger, A., Guasch, H., Lopez-Doval, J., Munoz, I., Proia, L., Ricart, M., Romani, A., Sabater, S. 2009. Is chemical contamination linked to the diversity of biological communities in rivers? TrAC - Trends in Analytical Chemistry 28(5), 592-602.

Ancion, P.Y., Lear, G., Dopheide, A., Lewis, G.D. 2013. Metal concentrations in stream biofilm and sediments and their potential to explain biofilm microbial community structure. Environmental Pollution 173, 117-124.

Fechner, L.C., Gourlay-Francé, C., Uher, E., Tusseau-Vuillemin, M.H. 2010a. Adapting an enzymatic toxicity test to allow comparative evaluation of natural freshwater biofilms' tolerance to metals. Ecotoxicology 19(7), 1302-1311.

Zhang, H., Davison, W. 1995. Performance Characteristics of Diffusion Gradients in Thin Films for the in Situ Measurement of Trace Metals in Aqueous Solution. Analytical Chemistry 67, $3391-3400$.

Clements, W.H., Carlisle, D.M., Lazorchak, J.M., Johnson, P.C. 2000. Heavy Metals Structure Benthic Communities in Colorado Mountain Streams. Ecological Applications 10(2), 626-638.

National Recommended Water Quality Criteria, U.S.E.P.A. 2009. Office of Water, Office of Science and http://water.epa.gov/scitech/swguidance/standards/criteria/current/index.cfm.

Technology

Fechner, L.C., Vincent-Hubert, F., Gaubert, P., Bouchez, T., Gourlay-Francé, C., TusseauVuillemin, M.H. 2010b. Combined eukaryotic and bacterial community fingerprinting of natural freshwater biofilms using Automated Ribosomal Intergenic Spacer Analysis. Fems Microbiology Ecology 74(3), 542-553.

Fechner, L.C., Gourlay-Francé, C., Tusseau-Vuillemin, M.H. 2011. Low exposure levels of urban metals induce heterotrophic community tolerance: a microcosm validation. Ecotoxicology 20(7), 793-802.

Eriksson, L., Johansson, E., Kettaneh-Wold, N., Trygg, J., Wikström, C., Wold, S. (2006) Multiand Megavariate Data Analysis, Umetrics Academy, Umean, Sweden.

Clarke, K.R. 1993. Non-parametric multivariate analyses of changes in community structure. Australian Journal of Ecology 18(1), 117-143.

Lehmann, V., Tubbing, G.M.J., Admiraal, W. 1999. Induced Metal Tolerance in Microbenthic Communities from Three Lowland Rivers with Different Metal Loads. Archives of Environmental Contamination and Toxicology 36(4), 384-391.

Uher, E., Mirande-Bret, C., Gourlay-Francé, C. 2011. Lessons from a large scale deployment of DGT in the Seine basin. Royal Society of Chemistry, Environmental Chemistry Group Bulletin January 2011.

Tusseau-Vuillemin, M.-H., Gourlay, C., Lorgeoux, C., Mouchel, J.-M., Buzier, R., Gilbin, R., Seidel, J.-L., Elbaz-Poulichet, F. 2007. Dissolved and bioavailable contaminants in the Seine river basin. Science of The Total Environment 375(1-3), 244-256.

Fechner, L.C., Dufour, M., Gourlay-Francé, C. 2012c. Pollution-induced community tolerance of freshwater biofilms: measuring heterotrophic tolerance to $\mathrm{Pb}$ using an enzymatic toxicity test. Ecotoxicology 21(8), 2123-2131. 
513 Nies, D.H. 2003. Efflux-mediated heavy metal resistance in prokaryotes. FEMS Microbiology 514 Reviews 27(2-3), 313-339.

515 Buzier, R., Tusseau-Vuillemin, M.H., Mouchel, J.M. 2006. Evaluation of DGT as a metal speciation tool in wastewater. Science of The Total Environment 358(1-3), 277-285.

517 Ferreira, D., Tousset, N., Ridame, C., Tusseau-Vuillemin, M.-H. 2008. More than inorganic 518 copper is bioavailable to aquatic mosses at environmentally relevant concentrations. 519 Environmental Toxicology and Chemistry 27(10), 2108-2116.

520 Bradac, P., Wagner, B., Kistler, D., Traber, J., Behra, R., Sigg, L. 2010. Cadmium speciation and accumulation in periphyton in a small stream with dynamic concentration variations. Environmental Pollution 158(3), 641-648.

Meylan, S., Behra, R., Sigg, L. 2004. Influence of Metal Speciation in Natural Freshwater on Bioaccumulation of Copper and Zinc in Periphyton: A Microcosm Study. Environ. Sci. Technol. 38(11), 3104-3111.

Niyogi, S., Wood, C.M. 2004. Biotic Ligand Model, a Flexible Tool for Developing SiteSpecific Water Quality Guidelines for Metals. Environmental Science \& Technology 38(23), 6177-6192.

529 Fierer, N., Morse, J.L., Berthrong, S.T., Bernhardt, E.S., Jackson, R.B. 2007. ENVIRONMENTAL CONTROLS ON THE LANDSCAPE-SCALE BIOGEOGRAPHY OF STREAM BACTERIAL COMMUNITIES. Ecology 88(9), 2162-2173.

Bent, S.J., Forney, L.J. 2008. The tragedy of the uncommon: Understanding limitations in the analysis of microbial diversity. ISME Journal 2(7), 689-695. C.D. 2013. Understanding the combined influence of fine sediment and glyphosate herbicide on stream periphyton communities. Water Research 47(14), 5110-5120. 
Table 1. CCU levels of the 13 sampling sites. $\mathrm{Cd}$ and $\mathrm{Zn}$ tolerance levels (normalized $\mathrm{EC}_{50}$ values expressed in $\left.\mathrm{mg}_{\mathrm{metal}} / \mathrm{g}_{\mathrm{TSS}}\right)$ and maximum inhibition levels $(\%)$ of biofilms collected at the 13 sites. $95 \%$ confidence intervals are shown in brackets.

\begin{tabular}{|c|c|c|c|c|c|}
\hline $\begin{array}{c}\text { sampling } \\
\text { sites }\end{array}$ & CCU & Cd tolerance & Cd \% max & Zn tolerance & Zn \% max \\
\hline site 1 & 0.232 & $8.15(5.81-10.49)$ & $76.43(72.92-80.63)$ & $16.48(10.90-22.06)$ & $74.81(73.48-78.46)$ \\
site 2 & 0.165 & $3.99(3.48-4.50)$ & $93.30(92.29-94.31)$ & $6.45(5.32-7.57)$ & $89.25(88.09-90.83)$ \\
site 3 & 0.163 & $3.59(2.27-4.91)$ & $84.98(81.10-90.29)$ & $9.19(6.08-12.29)$ & $77.80(75.00-82.74)$ \\
site 4 & 0.482 & $3.64(0.75-6.53)$ & $76.17(76.20-81.94)$ & $9.00(4.72-13.27)$ & $73.63(71.11-80.93)$ \\
site 5 & 0.271 & $2.04(1.87-2.21)$ & $96.00(95.11-96.91)$ & $4.10(3.43-4.78)$ & $93.85(91.71-96.63)$ \\
site 6 & 0.238 & $2.18(2.04-2.32)$ & $95.47(94.68-96.39)$ & $4.20(3.84-4.55)$ & $88.72(87.64-89.75)$ \\
site 7 & 0.298 & $1.39(1.08-1.71)$ & $94.60(92.85-96.73)$ & $2.05(1.60-2.51)$ & $87.50(85.80-89.54)$ \\
site 8 & 0.305 & $2.30(1.74-2.87)$ & $89.78(89.37-9.46)$ & $4.60(3.69-5.50)$ & $86.30(83.45-89.12)$ \\
site 9 & 0.182 & $4.38(1.52-7.24)$ & $78.65(76.44-80.85)$ & $2.80(2.15-3.45)$ & $81.33(80.45-82.58)$ \\
site 10 & 0.572 & $4.68(0-12.70)$ & $75.44(74.12-86.24)$ & $10.39(5.14-15.64)$ & $69.30(67.62-74.17)$ \\
site 11 & 0.727 & $4.21(2.94-5.48)$ & $77.20(75.93-78.60)$ & $4.51(2.73-6.30)$ & $76.74(73.59-81.97)$ \\
site 12 & 0.151 & $3.69(2.62-4.76)$ & $92.16(90.17-94.34)$ & $3.66(2.64-4.68)$ & $86.23(85.38-87.37)$ \\
site 13 & 0.539 & $4.99(3.35-6.63)$ & $73.74(73.06-74.64)$ & $3.77(2.79-4.75)$ & $68.17(66.31-70.60)$ \\
\hline
\end{tabular}


Table 2. Mean dissolved metal contamination levels at the 13 sampling sites $(n=3)$. Concentrations are expressed in $\mu \mathrm{g} / \mathrm{L}$.

\begin{tabular}{|c|c|c|c|c|c|c|c|c|}
\hline sampling sites & Cd & $\mathrm{Cr}$ & Co & $\mathrm{Cu}$ & Mn & $\mathrm{Ni}$ & $\mathbf{P b}$ & $\mathrm{Zn}$ \\
\hline site 1 & 0.01 & 0.28 & 0.12 & 0.75 & 7.61 & 0.79 & 0.11 & 1.22 \\
\hline site 2 & 0.01 & 0.28 & 0.13 & 0.64 & 5.93 & 0.89 & 0.06 & 0.83 \\
\hline site 3 & 0.01 & 0.33 & 0.12 & 0.50 & 6.88 & 0.82 & 0.15 & 2.23 \\
\hline site 4 & 0.01 & 0.31 & 0.24 & 1.40 & 25.30 & 1.23 & 0.19 & 6.80 \\
\hline site 5 & 0.01 & 0.04 & 0.13 & 0.89 & 10.16 & 0.98 & 0.06 & 1.58 \\
\hline site 6 & 0.01 & 0.03 & 0.14 & 0.89 & 6.96 & 1.11 & 0.10 & 3.00 \\
\hline site 7 & 0.01 & 0.13 & 0.18 & 0.84 & 17.84 & 1.35 & 0.06 & 1.89 \\
\hline site 8 & 0.01 & 0.17 & 0.18 & 0.95 & 14.88 & 1.35 & 0.12 & 2.91 \\
\hline site 9 & 0.01 & 0.15 & 0.10 & 0.37 & 11.83 & 0.69 & 0.07 & 0.95 \\
\hline site 10 & 0.04 & 0.23 & 0.29 & 1.87 & 12.60 & 2.30 & 0.21 & 9.07 \\
\hline site 11 & 0.02 & 0.15 & 0.40 & 1.05 & 49.84 & 2.37 & 0.07 & 5.46 \\
\hline site 12 & 0.00 & 0.49 & 0.15 & 0.44 & 7.45 & 1.19 & 0.05 & 2.07 \\
\hline site 13 & 0.02 & 1.48 & 0.53 & 0.92 & 15.78 & 1.49 & 0.11 & 46.65 \\
\hline $\begin{array}{l}\text { mean for all } 13 \text { sites } \\
\text { water quality standards }\end{array}$ & 0.01 & 0.31 & 0.21 & 0.89 & 14.85 & 1.27 & 0.11 & 6.51 \\
\hline EU WFD EQSs ${ }^{1}$ & 0.25 & & & 1.4 & & 4 & 1.2 & 7.8 \\
\hline US EPA CCCs ${ }^{2}$ & 0.19 & & & 26 & & 150 & 19.65 & 298.64 \\
\hline \multicolumn{9}{|c|}{$\begin{array}{l}{ }^{1} \text { European Union Water Framework Directive (EU WFD) EQSs are given for waters with CaCO3 > } 200 \\
\text { mg/L. Water hardness varies between } 173 \text { and } 351 \mathrm{mg} / \mathrm{L} \mathrm{CaCO} 3 \text { (only site } 1 \text { has a water hardness } \\
\text { below } 200 \mathrm{mg} / \text { )L. }\end{array}$} \\
\hline \multicolumn{9}{|c|}{${ }^{2} \operatorname{CCCs}$ (Criterion Continuous Concentrations) were corrected using hardness - dependent parameters } \\
\hline \multicolumn{9}{|c|}{ from Appendix B of the National Recommended Water Quality Criteria from the EPA. The CCCs given } \\
\hline \multicolumn{9}{|c|}{ here are those obtained for site 9 which has the highest water hardness $\left(351 \mathrm{mg} / \mathrm{L} \mathrm{CaCO}_{3}\right)$} \\
\hline
\end{tabular}


Table 3. Variable importance (Variable Influence in the Projection) in the PLS model and corresponding regression coefficients for each $\mathrm{Y}$ variable: $\mathrm{Cd}$ tolerance, $\mathrm{Zn}$ tolerance and maximum \% inhibition of $\beta$-glucosidase activity obtained with $\mathrm{Cd}$ and $\mathrm{Zn}$. Only variables with VIP > 0.8 are represented. Metal concentrations are indicated by 'lab' for labile. 'dis' for dissolved and 'tot' for total metal concentrations.

\begin{tabular}{|c|c|c|c|c|c|}
\hline Variable & VIP & CoefftolCd & CoefftolZn & Coeffmax\%Cd & Coeffmax\%Zn \\
\hline $\mathrm{pH}$ & 1.442 & -0.062 & -0.139 & 0.036 & 0.085 \\
$\mathrm{POC}$ & 1.435 & 0.152 & 0.149 & -0.165 & -0.133 \\
dis $\mathrm{Cr}$ & 1.329 & 0.126 & 0.054 & -0.107 & -0.140 \\
$\mathrm{NH}_{4}^{+}$ & 1.327 & -0.231 & -0.112 & 0.236 & 0.144 \\
dis $\mathrm{Pb}$ & 1.314 & 0.066 & 0.164 & -0.116 & -0.120 \\
tot $\mathrm{Pb}$ & 1.217 & 0.080 & 0.112 & -0.125 & -0.132 \\
tot $\mathrm{Zn}$ & 1.138 & 0.101 & 0.024 & -0.106 & -0.136 \\
$\mathrm{Chl}-\mathrm{a}$ & 1.129 & -0.169 & -0.053 & 0.163 & 0.099 \\
lab Ni & 1.074 & -0.132 & -0.043 & 0.104 & 0.102 \\
lab Cr & 1.061 & -0.021 & -0.122 & 0.010 & 0.005 \\
$\mathrm{Na}{ }^{+}$ & 1.050 & -0.084 & -0.069 & 0.052 & 0.037 \\
$\mathrm{Alkalinity}^{+}$ & 1.032 & -0.052 & -0.120 & 0.042 & 0.037 \\
$\mathrm{DW}$ & 1.032 & -0.075 & -0.083 & 0.047 & 0.021 \\
$\mathrm{Mg}{ }^{2+}$ & 1.018 & -0.034 & -0.039 & -0.042 & 0.029 \\
dis $\mathrm{Zn}$ & 1.014 & 0.028 & 0.016 & -0.027 & -0.082 \\
tot $\mathrm{Cr}$ & 1.014 & 0.133 & -0.016 & -0.147 & -0.132 \\
tot $\mathrm{Cd}$ & 1.006 & 0.082 & -0.005 & -0.074 & -0.092 \\
tot $\mathrm{Co}$ & 0.985 & 0.061 & -0.035 & -0.067 & -0.061 \\
dis $\mathrm{Co}$ & 0.980 & 0.027 & -0.005 & -0.019 & -0.055 \\
tot Ni & 0.976 & -0.030 & -0.064 & 0.026 & 0.022 \\
$\mathrm{AFDW}_{\text {dis }}$ & 0.953 & -0.118 & -0.052 & 0.083 & 0.050 \\
dis & 0.950 & -0.084 & -0.024 & 0.097 & 0.047 \\
lab Co & 0.930 & 0.004 & -0.042 & -0.048 & -0.020 \\
tot $\mathrm{Cu}$ & 0.929 & 0.101 & 0.089 & -0.158 & -0.107 \\
$\mathrm{SO}_{4}^{2-}$ & 0.924 & 0.026 & -0.036 & -0.060 & -0.038 \\
tot $\mathrm{Mn}$ & 0.920 & 0.073 & 0.017 & -0.128 & -0.065 \\
dis $\mathrm{Cu}$ & 0.914 & -0.069 & 0.058 & 0.059 & 0.019 \\
$\mathrm{Cl}^{-}$ & 0.906 & -0.044 & -0.035 & 0.024 & 0.009 \\
\hline
\end{tabular}


Figure 1: Map of the sampling sites in the Seine river basin, North of France.

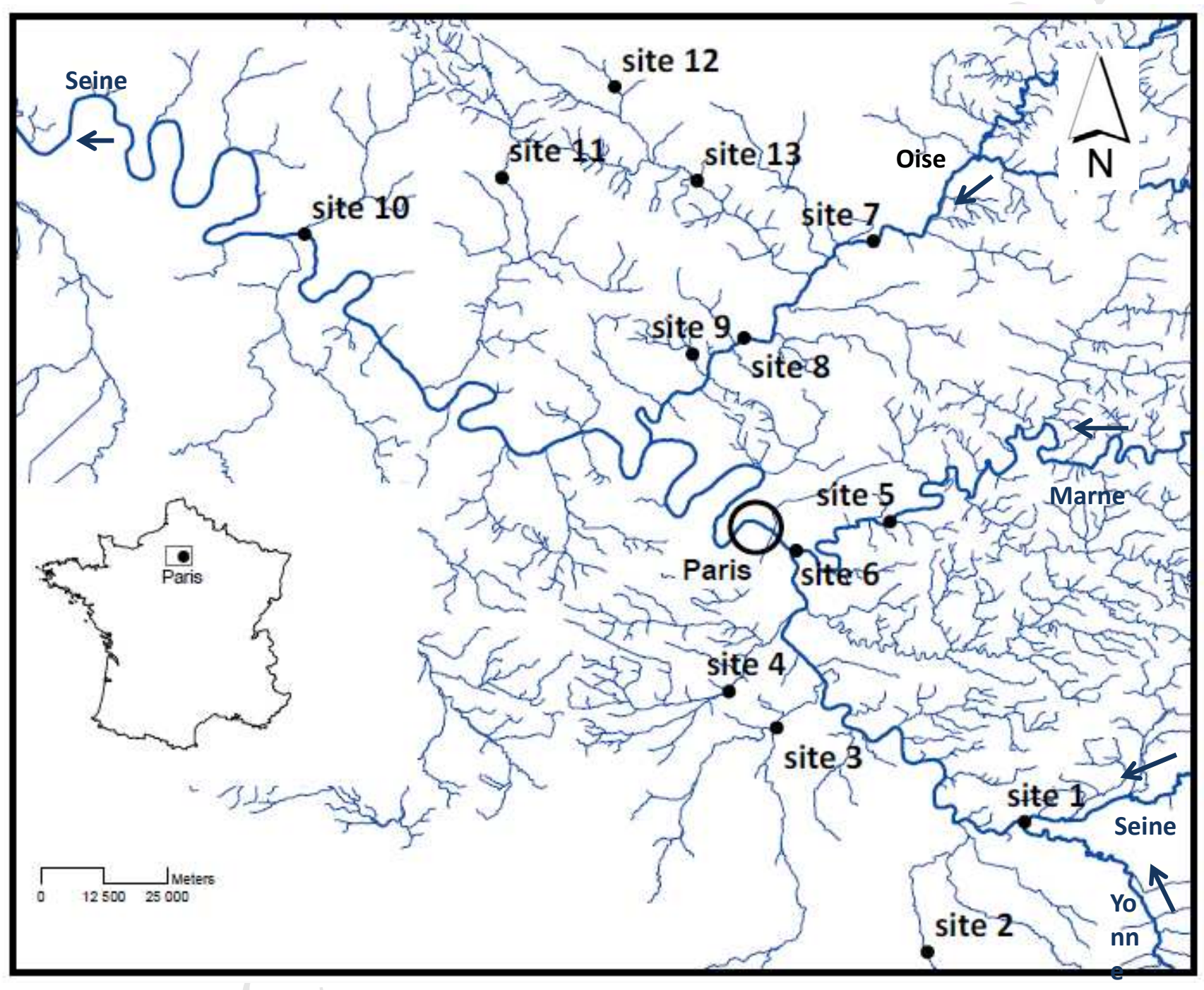

The location of the city of Paris is indicated by a circle. The names of main rivers are pointed out and arrows show the direction of the flow. 
Fig. 2.

PCA score plot (a) and loading plot (b) of the environmental parameters (physico-chemical data and total, dissolved and labile metal contamination data) of the 13 sites. Metal concentrations are indicated by 'lab' for labile, 'Diss' for dissolved and 'tot' for total metal concentrations.
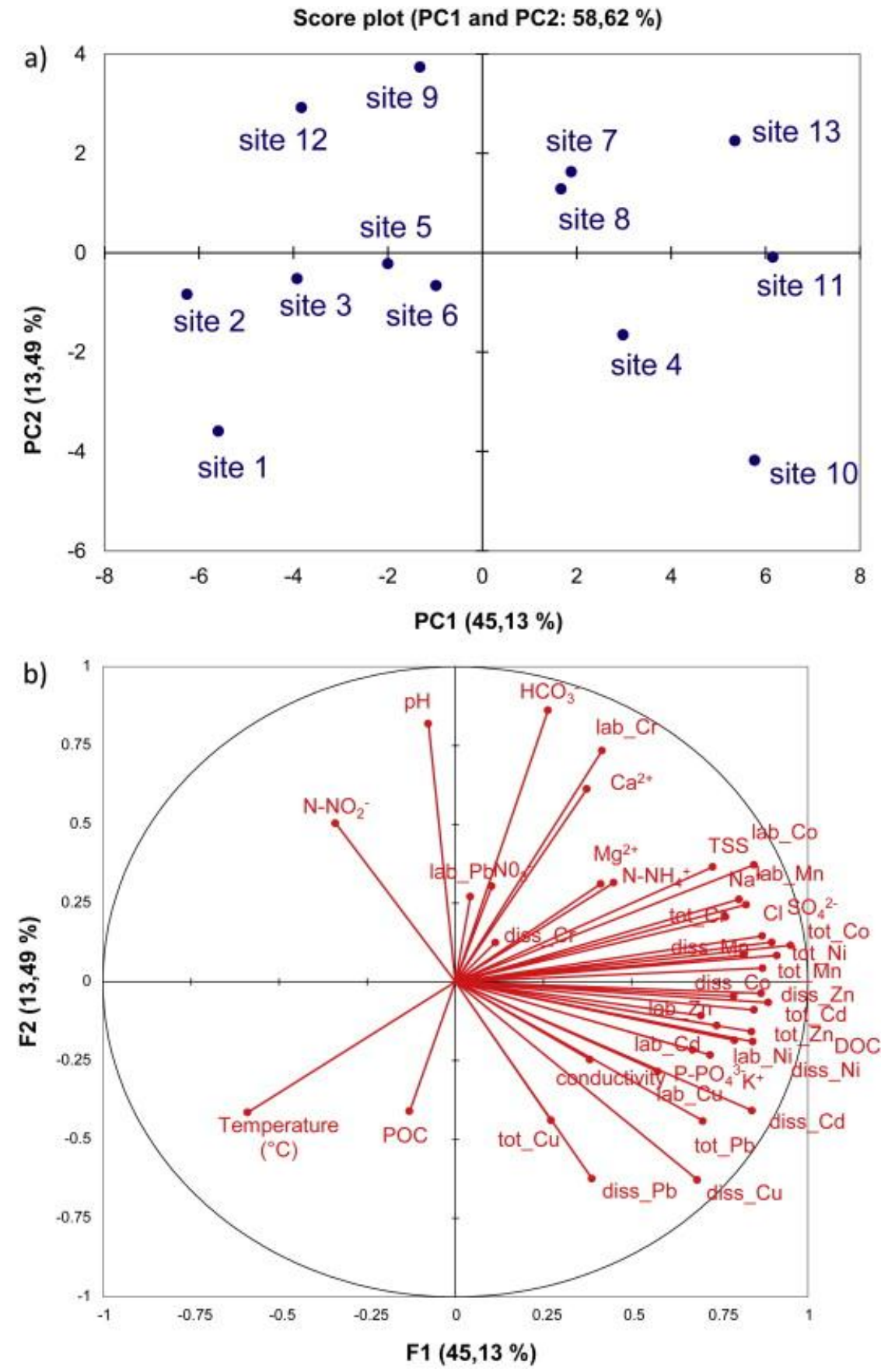
Figure 3. 2D projections (along the first two components) of 3D-nMDS plots of bacterial (a) and eukaryotic (b) ARISA fingerprints (stress values are $3.58 \%$ (a) and 4.86\%. (b) for 3D plots).

Each ARISA profile (biofilm sample) is characterized by three parameters (CCU of the sampling site, $\mathrm{Cd}$ and $\mathrm{Zn}$ biofilm tolerance), each represented as a lower-case letter (m, c and $\mathrm{z}$ ) or capital letter (M, C and Z) whether the corresponding parameter is above or below the mean calculated for all 13 sites.

Legend:

$\begin{array}{r}* \mathrm{mcz} \\ \star \mathrm{mcz} \\ +\mathrm{mCz} \\ \times \mathrm{mcz} \\ \nabla \mathrm{Mcz} \\ \nabla \mathrm{MCz} \\ -\mathrm{Mcz} \\ \hline\end{array}$

\begin{tabular}{|l|l|l|}
\hline & Low & high \\
\hline CCU & $\mathrm{m}$ & $\mathrm{M}$ \\
\hline Cd tolerance & $\mathrm{c}$ & $\mathrm{C}$ \\
\hline Zn tolerance & $\mathrm{z}$ & $\mathrm{Z}$ \\
\hline
\end{tabular}




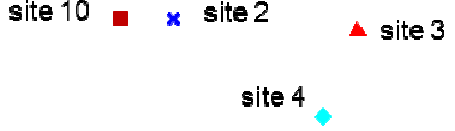

site 7 .

$-$

site 6

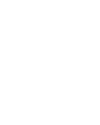

- site 12

site 11

site 13

- site 5 
b

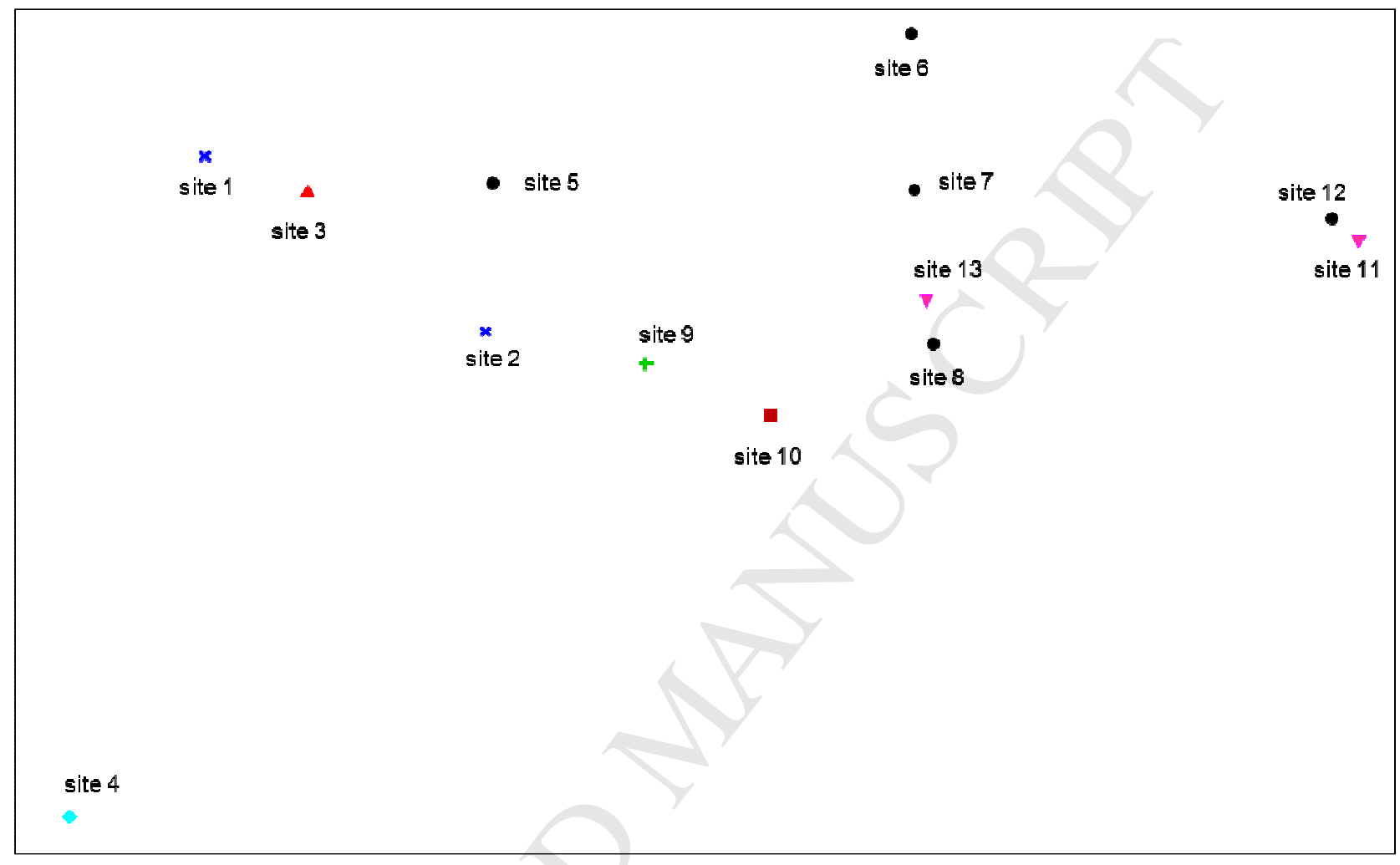


ARISA profiles of biofilms with high $\mathrm{Zn}$ tolerance levels $(\mathrm{Z})$ are represented by: $\boldsymbol{\Lambda}, \times, \mathbf{m}, \bullet$. ARISA profiles of biofilms with high Cd tolerance levels (C) are represented by: $\boldsymbol{\nabla} \times+$. ARISA profiles of biofilms collected at sites with high CCU (M) are represented by: $\mathbf{\nabla} \bullet$. 
Highlights:

River biofilms were collected on 13 sites with low metallic contamination levels

Multivariate analysis shows that biofilm metal tolerance was linked to contamination

Environmental parameters also modulate biofilm tolerance levels

Biofilms with similar tolerance levels have similar ARISA profiles

Biofilms are potential sensitive indicators of diffuse, low-level contamination 


\title{
Supporting information
}

\section{Linking community tolerance and structure with}

\author{
low metallic contamination: a field study on 13
}

\section{biofilms sampled across the Seine river basin.}

\author{
Lise C. Fechner ${ }^{123^{*}}$, Catherine Gourlay-Francé ${ }^{13}$, Marie-Hélène Tusseau-Vuillemin ${ }^{4}$ \\ ${ }^{1}$ Irstea Antony - Unité de Recherche Hydrosystèmes et Bioprocédés (HBAN)
}

1 rue Pierre-Gilles de Gennes, CS 10030 F-92761 Antony Cedex, France

${ }^{2}$ AgroParisTech, F-75005 Paris, France

${ }^{3}$ FIRE, FR-3020, 4 Place Jussieu 75005, Paris, France

${ }^{4}$ IFREMER - Technopolis 40,155 rue Jean-Jacques Rousseau, 92138 Issy-Les-Moulineaux, France

"Tel: +33140966568

"Fax: +33140966199

"E-mail: lise.fechner@irstea.fr 
Table S1. Mean values $(n=3)$ of physico-chemical parameters of river water at the 13 sampling sites. lonic concentrations and Total Suspended Solids in river water (TSSw) are expressed in $\mathrm{mg} / \mathrm{L}$, conductivity in $\mu \mathrm{S} / \mathrm{cm}$, DOC in $\mathrm{mgC} / \mathrm{L}$ and POC in $\mathrm{mgC} / \mathrm{gTSS}$. nd: not determined.

\begin{tabular}{|c|c|c|c|c|c|c|c|c|c|c|c|c|c|c|c|c|c|}
\hline sampling sites & $\mathrm{HCO}_{3}^{-}$ & $\mathrm{Na}^{+}$ & $\mathrm{K}^{+}$ & $\mathrm{Mg}^{2+}$ & $\mathrm{Ca}^{2+}$ & $\mathrm{Cl}^{-}$ & $\mathrm{SO}_{4}{ }^{2-}$ & $\mathrm{NO}_{3}^{-}$ & $\mathrm{P}-\mathrm{PO}_{4}{ }^{3-}$ & $\mathrm{N}-\mathrm{NO}_{2}$ & $\mathrm{~N}-\mathrm{NH}_{4}{ }^{+}$ & $\mathrm{T}\left({ }^{\circ} \mathrm{C}\right)$ & $\mathrm{pH}$ & conductivity & TSS & DOC & POC \\
\hline site 1 & 168.8 & 7.0 & 2.1 & 2.9 & 64.3 & 13.1 & 11.1 & 11.6 & 0.15 & 0.02 & nd & 21.7 & 7.71 & 699.3 & 4.6 & 2.3 & 131.0 \\
\hline site 2 & 233.8 & 12.4 & 3.2 & 2.8 & 92.7 & 28.0 & 16.2 & 22.5 & 0.14 & 0.04 & nd & 18.8 & 7.74 & 553.3 & 4.2 & 2.5 & 139.9 \\
\hline site 3 & 239.9 & 11.1 & 3.2 & 5.6 & 93.2 & 24.6 & 18.0 & 27.5 & 0.15 & 0.08 & nd & 16.3 & 7.70 & 943.7 & 12.0 & 2.0 & 137.5 \\
\hline site 4 & 213.5 & 19.4 & 5.1 & 8.6 & 84.3 & 37.2 & 38.4 & 21.0 & 0.29 & 0.04 & 0.04 & 16.1 & 7.71 & 574.7 & 16.9 & 3.8 & 108.3 \\
\hline site 5 & 197.2 & 14.6 & 2.4 & 9.2 & 69.8 & 19.9 & 28.7 & 7.9 & 0.16 & 0.05 & 0.06 & 17.5 & 7.89 & 1178.3 & 9.5 & 2.8 & 40.6 \\
\hline site 6 & 201.3 & 16.1 & 2.8 & 9.6 & 71.8 & 22.5 & 34.3 & 8.8 & 0.17 & 0.06 & 0.04 & 17.7 & 7.85 & 1386.7 & 13.2 & 2.8 & 56.5 \\
\hline site 7 & 280.6 & 31.1 & 5.4 & 10.2 & 102.5 & 41.4 & 48.8 & 18.2 & 0.17 & 0.04 & 0.09 & 16.8 & 7.93 & 1158.7 & 13.4 & 3.0 & 25.2 \\
\hline site 8 & 278.6 & 32.4 & 5.0 & 10.2 & 100.7 & 41.2 & 52.3 & 18.7 & 0.18 & 0.04 & 0.06 & 15.7 & 7.99 & 631.3 & 8.3 & 3.1 & 78.8 \\
\hline site 9 & 307.0 & 17.4 & 2.2 & 20.4 & 107.0 & 34.1 & 51.0 & 29.8 & 0.16 & 0.06 & nd & 12.6 & 8.00 & 670.3 & 20.6 & 2.5 & 48.6 \\
\hline site 10 & 211.5 & 21.3 & 5.5 & 8.3 & 85.5 & 56.7 & 68.3 & 25.7 & 0.24 & nd & 0.02 & 11.7 & 7.58 & 1494.3 & 12.3 & 5.9 & 65.1 \\
\hline site 11 & 250.1 & 25.8 & 7.9 & 6.5 & 97.7 & 60.7 & 81.5 & 16.0 & 0.22 & 0.01 & 0.01 & 9.1 & 7.76 & 1952.7 & 34.5 & 10.6 & 97.9 \\
\hline site 12 & 278.6 & 7.8 & 2.0 & 3.6 & 86.5 & 22.0 & 9.2 & 27.6 & 0.19 & 0.02 & 0.06 & 9.7 & 7.86 & 802.7 & 10.6 & 2.7 & 80.8 \\
\hline site 13 & 284.7 & 31.2 & 3.8 & 4.7 & 97.1 & 47.0 & 81.0 & 21.7 & 0.18 & 0.08 & 0.11 & 10.3 & 7.83 & 599.7 & 18.7 & 4.2 & 123.0 \\
\hline
\end{tabular}


Table S2. Parameters used Parameters for Calculating Freshwater Dissolved Metals Criteria That Are Hardness-Dependent according to US EPA.

\begin{tabular}{cccc}
\hline metal & $\mathbf{m C}$ & $\mathbf{b C}$ & conversion factor \\
\hline $\mathrm{Cd}$ & 0.7409 & -4.719 & $1.101672 \times(\operatorname{Ln}([$ hardness $]) \times$ \\
$\mathrm{Cu}$ & 0.8545 & -1.702 & $0.04838)$ \\
$\mathrm{Pb}$ & 1.273 & -4.705 & 0.96 \\
$\mathrm{Ni}$ & 0.846 & 0.0584 & $0.145712)$ \\
$\mathrm{Zn}$ & 0.8473 & 0.884 & 0.997 \\
\hline
\end{tabular}

Source: National Recommended Water Quality Criteria, http://water.epa.gov/scitech/swguidance/standards/criteria/current/index.cf 
Table S3. Physico-chemical parameters of Montdore mineral waters (in $\mathrm{mg} / \mathrm{L}$ )

\begin{tabular}{|r|r|r|r|r|r|r|r|}
\hline $\mathrm{HCO}_{3}{ }^{-}$ & $\mathrm{Na}^{+}$ & \multicolumn{1}{|c|}{$\mathrm{K}^{+}$} & $\mathrm{Mg}^{2+}$ & $\mathrm{Ca}^{2+}$ & $\mathrm{Cl}^{-}$ & $\mathrm{SO}_{4}{ }^{2-}$ & $\mathrm{NO}_{3}{ }^{-}$ \\
\hline 25.8 & 2.7 & 0.9 & 1.7 & 4.1 & 0.9 & 1.14 & 0.8 \\
\hline
\end{tabular}


Table S4. Mean total (a) and labile (b) metal contamination levels at the 13 sampling sites $(n=3)$.

Concentrations are expressed in $\mu \mathrm{g} / \mathrm{L}$.

a.

$\begin{array}{ccccccccc}\begin{array}{c}\text { Sampling } \\ \text { sites }\end{array} & \mathbf{C d} & \mathbf{C r} & \mathbf{C o} & \mathbf{C u} & \mathbf{M n} & \mathbf{N i} & \mathbf{P b} & \mathbf{Z n} \\ \text { site 1 } & 0.03 & 0.55 & 0.15 & 7.05 & 16.41 & 1.17 & 1.09 & 6.71 \\ \text { site 2 } & 0.02 & 0.07 & 0.14 & 1.61 & 11.24 & 1.24 & 0.48 & 2.69 \\ \text { site 3 } & 0.03 & 0.30 & 0.13 & 3.53 & 17.92 & 1.06 & 1.74 & 7.21 \\ \text { site 4 } & 0.05 & 1.30 & 0.43 & 6.08 & 42.49 & 2.01 & 2.58 & 16.01 \\ \text { site 5 } & 0.03 & 0.49 & 0.21 & 3.09 & 17.11 & 1.65 & 0.66 & 4.40 \\ \text { site 6 } & 0.04 & 0.89 & 0.27 & 4.99 & 20.46 & 1.88 & 1.39 & 8.36 \\ \text { site 7 } & 0.04 & 0.96 & 0.39 & 6.43 & 35.29 & 2.63 & 1.10 & 11.17 \\ \text { site 8 } & 0.04 & 0.64 & 0.31 & 4.76 & 27.80 & 2.32 & 1.15 & 7.63 \\ \text { site 9 } & 0.04 & 1.14 & 0.32 & 3.46 & 27.66 & 1.90 & 0.89 & 5.84 \\ \text { site 10 } & 0.09 & 1.75 & 0.67 & 4.59 & 31.62 & 3.41 & 3.42 & 26.14 \\ \text { site 11 } & 0.06 & 1.23 & 1.01 & 2.66 & 111.02 & 3.49 & 1.41 & 15.32 \\ \text { site 12 } & 0.04 & 0.87 & 0.25 & 0.88 & 12.91 & 1.75 & 0.51 & 4.89 \\ \text { site 13 } & 0.07 & 6.12 & 0.88 & 2.85 & 39.42 & 2.36 & 2.01 & 60.03\end{array}$

b.

$\begin{array}{ccccccccc}\begin{array}{c}\text { Sampling } \\ \text { sites }\end{array} & \mathbf{C d} & \mathbf{C r} & \mathbf{C o} & \mathbf{C u} & \mathbf{M n} & \mathbf{N i} & \mathbf{P b} & \mathbf{Z n} \\ \text { site 1 } & 0.001 & 0.02 & 0.01 & 0.11 & 3.22 & 0.12 & 0.02 & 0.92 \\ \text { site 2 } & 0.001 & 0.01 & 0.00 & 0.09 & 1.81 & 0.16 & 0.03 & 0.49 \\ \text { site 3 } & 0.002 & 0.03 & 0.01 & 0.10 & 2.67 & 0.10 & 0.13 & 1.08 \\ \text { site 4 } & 0.002 & 0.04 & 0.04 & 0.30 & 14.02 & 0.29 & 0.13 & 1.90 \\ \text { site 5 } & 0.002 & 0.08 & 0.03 & 0.24 & 8.23 & 0.58 & 0.05 & 0.85 \\ \text { site 6 } & 0.002 & 0.10 & 0.02 & 0.19 & 4.27 & 0.22 & 0.08 & 2.05 \\ \text { site 7 } & 0.003 & 0.09 & 0.03 & 0.19 & 11.78 & 0.45 & 0.04 & 1.66 \\ \text { site 8 } & 0.005 & 0.18 & 0.04 & 0.25 & 7.55 & 0.36 & 0.09 & 2.10 \\ \text { site 9 } & 0.002 & 0.12 & 0.03 & 0.18 & 6.09 & 0.16 & 0.03 & 1.08 \\ \text { site 10 } & 0.009 & 0.02 & 0.03 & 0.38 & 5.36 & 0.50 & 0.02 & 2.94 \\ \text { site 11 } & 0.002 & 0.05 & 0.10 & 0.10 & 25.94 & 0.57 & 0.03 & 1.03 \\ \text { site 12 } & 0.001 & 0.07 & 0.03 & 0.05 & 5.34 & 0.09 & 0.04 & 0.22 \\ \text { site 13 } & 0.002 & 0.51 & 0.13 & 0.17 & 12.13 & 0.27 & 0.11 & 8.78\end{array}$


Figure S1. 3D MDS of ARISA bacterial (a) and eukaryotic (b) profiles. Stress values are $3.58 \%$ (a) and $4.86 \%$. (b). Each fingerprint (biofilm sample) is characterized by three parameters (CCU of the sampling site, $\mathrm{Cd}$ and $\mathrm{Zn}$ biofilm tolerance), each represented as a lower-case letter $(\mathrm{m}, \mathrm{c}$ and $\mathrm{z})$ or capital letter $(\mathrm{M}, \mathrm{C}$ and $\mathrm{Z})$ whether the corresponding parameter is above or below the mean calculated for all 13 sites. For each biofilm sample (sampling site) ARISA profils were obtained in triplicates.

Legend of the 3-dimensional plot:

\begin{tabular}{|l|l|l|}
\hline & Low & high \\
\hline CCU & $\mathrm{m}$ & $\mathrm{M}$ \\
\hline Cd tolerance & $\mathrm{c}$ & $\mathrm{C}$ \\
\hline Zn tolerance & $\mathrm{z}$ & $\mathrm{Z}$ \\
\hline
\end{tabular}

- mcz

- mcZ

- $\mathrm{mCz}$

- $\mathrm{mCZ}$

- McZ

- MCZ MCZ 


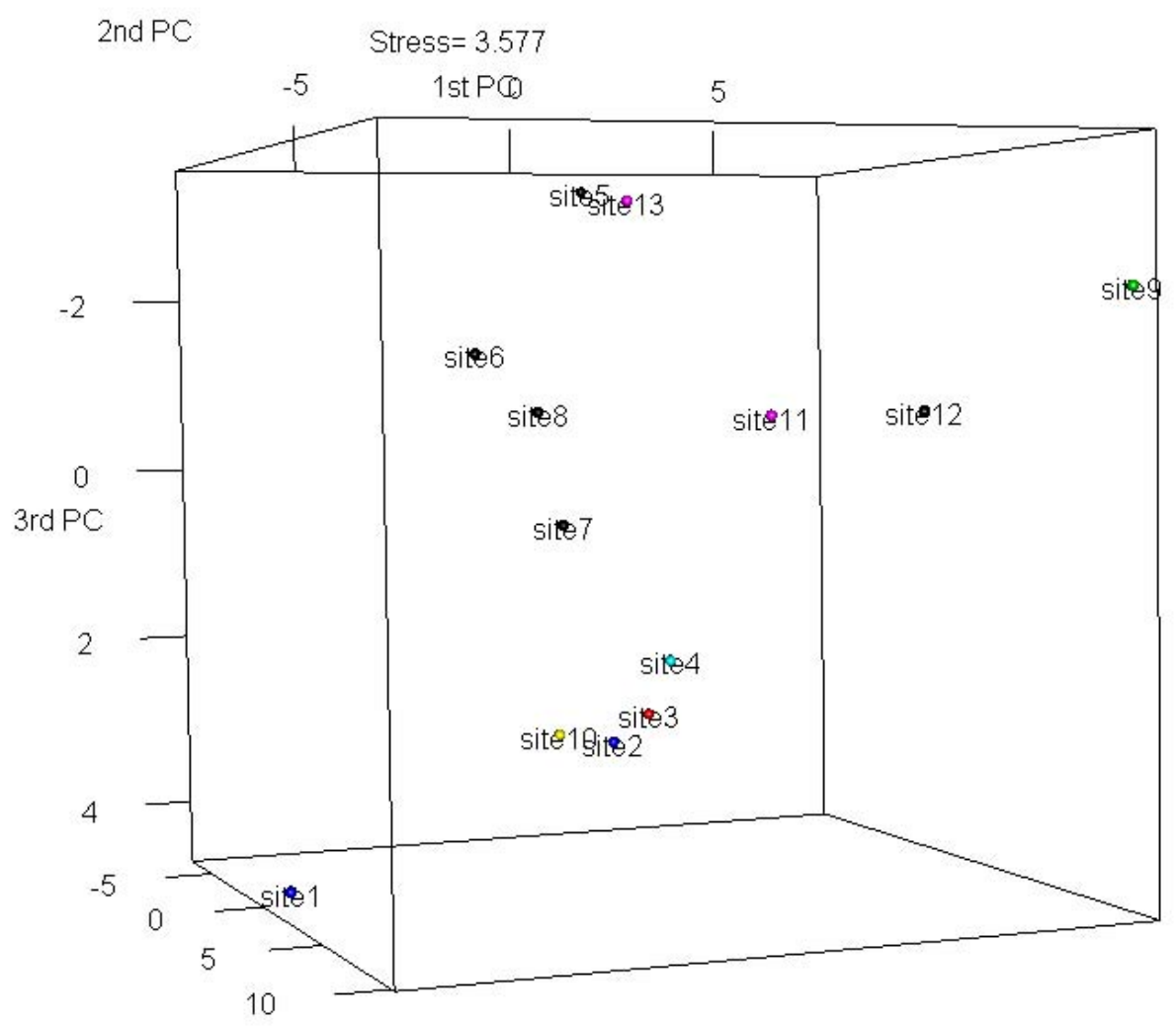

Non-metric multidimensional scaling 


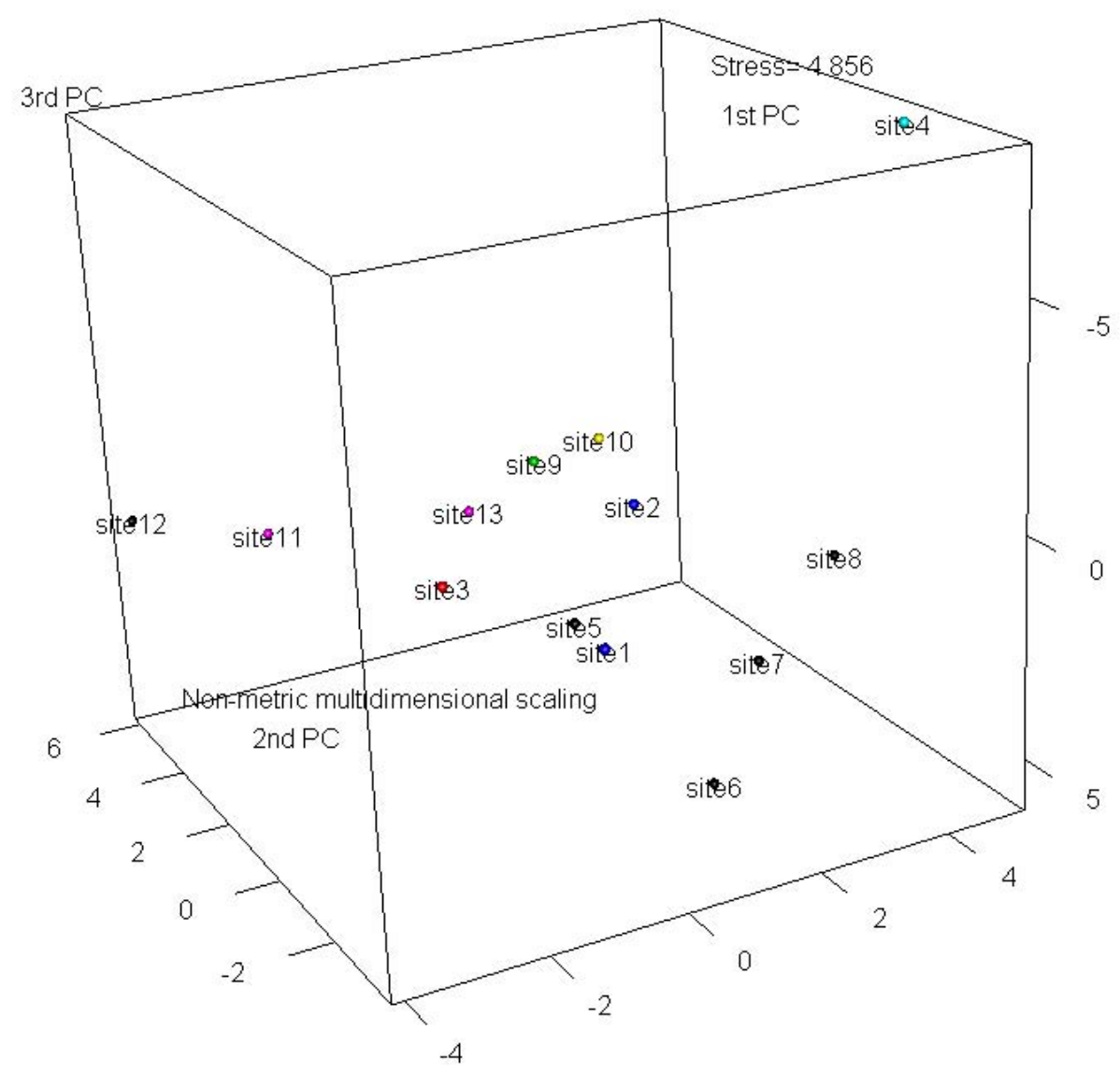

b 